\title{
Adoption of Improved Sheep Rearing Practices in the Eastern Part of Rajasthan, India
}

\author{
Bacchu Singh $^{1^{*}}$, K. C. Meena ${ }^{2}$, Deepa Indoria ${ }^{3}$ and G. S. Meena ${ }^{4}$ \\ ${ }^{1}$ Krishi Vigyan Kendra, Hindaun (Karauli), Agriculture University Kota, India \\ ${ }^{2}$ College of Agriculture, Agriculture University, Kota, India \\ ${ }^{3}$ Krishi Vigyan Kendra, Chittorgarh, MPUA\&T, Udaipur, India \\ ${ }^{4}$ Krishi Vigyan Kendra, Bundi, Agriculture University Kota, India \\ *Corresponding author
}

\section{A B S T R A C T}

\begin{tabular}{|l|}
\hline Ke y w o r d s \\
$\begin{array}{l}\text { Extension } \\
\text { strategies, profile of } \\
\text { sheep farmers }\end{array}$ \\
\hline Article Info \\
\hline $\begin{array}{l}\text { Accepted: } \\
\text { 05 April 2020 } \\
\text { Available Online: } \\
\text { 10 May } 2020\end{array}$ \\
\hline
\end{tabular}

The present study was aimed at understanding the socio-economic conditions and adoption of sheep management practices in Karauli district of Rajasthan, India as it serves as a benchmark for evolving meaningful extension strategies and other policy interventions. The scenario in Karauli district revealed that sheep production is in the hands of traditional farmers; rearing under the extensive system of management. Most of the farmers had a poor socio-economic background with illiteracy. Majority is rearing a hairy coated dual purpose breed with small flock sizes ranging from 25 to 50 heads. Non adoption of ram rotation, periodic culling of unproductive ewes, flushing, supplementary feeding of pregnant and lactating ewes and weaning indicated the very low level of adoption of management practices. Immunization for endemic diseases is followed at the behest of Animal Husbandry department. Health care measures are followed to the moderate extent only. Because of significant influence of the stockists, the farmers are depending on them for selection of suitable deworming agents rather than a veterinarian leading to exploitation.

\section{Introduction}

Generally, shepherds follow certain traditional practices but modern scientific practices do play a very important role in improving production. The improved husbandry practices in the livestock farming make it more sustainable and profitable livelihood especially to the rural backward people. The information on the existing sheep husbandry scenario helps to formulate the strategies for adoption of better husbandry practices.

Hence an attempt has been made in the present study to find out the profile of the sheep farmers, as it give an overview of their socio economic background and to find out 
the extent of adoption, so as to address the impediments coming in its way. These aspects help the planners and extension agencies to choose and implement proper ways and means.

\section{Materials and Methods}

The present study was taken up Karauli district, where the sheep farming is being practiced since ages. An expost facto research design was used in the present study. A total for 120sheep-rearingfarmers were randomly selected for the data collection. The data were collect from the farmers by the investigators with the help of a pre structured interview schedule and suitable statistical tools were used for analysis the results of the study.

\section{Results and Discussion}

\section{Profile characteristics of goat farmers Education}

The development of individual is significantly influenced by his education and the experience as it brings change in knowledge, skill and attitude (KSA) but it was revealed from the Table 1 that maximum of the sheep farmers were literates $(42.50 \%)$, followed by illiterate $(32.50 \%)$, up to primary $(22.50 \%)$ and only 2.50 percent were up to secondary.

This clearly indicated that the sheep farmers were illiterate which may due to their low socio economic status, many of them are nomadic, and hence they deprived of the functional literacy in many cases.

\section{Family}

It was evident from Table 1 that the majority of the sheep farmers $(65.83 \%)$ were still living in the joint family system, despite the opposite trend as mostly seen in urban areas (Raju et al., 2006) please reference this type of statement). Nuclear families were about $34.17 \%$ of the respondents, which may be due to their education and exposure to mass media. (A Joint Hindu family consists of all persons lineally descended from a common ancestor, and includes their wives and unmarried daughters). A nuclear family can be any size, as long as the family can support itself and there are only parents and children)

\section{Family size}

The family size was more than six persons in many of the families $(79.17 \%)$ as evidenced by Table 1 . The remaining $20.83 \%$ of the respondents were having a family size of less than five persons. The trend indicated that the sheep farmers had not recognized the advantages of small families. It is the general perception of sheep growers to prefer a bigger family which helps to share the workload. Especially male children are of immense help during migration and penning season. The prevailing situation due to the fact that the majority of them were illiterate and had limited / no access to various sources of information.

\section{Livestock possession}

Table 1 revealed that the majority of sheep farmers possessed buffaloes $(74.17 \%)$, followed by goat (49.17\%), backyard poultry $(30.83 \%)$ and cattle (14.17\%).Generally, small and marginal farmers prefer milch buffaloes and depending upon their need and efficiently utilize the agricultural by-products. Information on possession of the livestock helps in understanding the choice of shepherds and the compatibility with sheep production.

\section{Breed and flock information}

It is essential to identify different aspects of sheep possession, as husbandry practices 
depend on the type, number, source of procurement of animals etc. The data were obtained from the sheep farmers and presented in Table 2.

From Table 2, it was evident that the majority of the sheep farmers had non-descript or mixed type of flock and the remaining $27.50 \%$ possessed malpuri breed. People prefer this breed as suits to the existing climatic conditions. This breed is fairly wellbuilt, with long legs and face is light brown.

\section{Flock size}

A significant variation in the average size of the flock was found among the sheep farmers of the study area. The variation in the size influenced by their socio-economic status. The majority of the farmers $(50.83 \%)$ possessed their flock size between 25 and 50 numbers, followed by less than 25 numbers (18.33\%), equal numbers (10.83\%) distributed into categories i.e. 51-75 \& 76-100 and more than $100(9.17 \%)$.

This trend indicates that sheep possession varied widely among the respondents. It is an important enterprise providing livelihood to many of the respondents. As half of the respondents had a size between 26 and 50, it can be concluded that this number is the minimum viable unit for a small entrepreneur.

\section{Sources of animals}

\section{Rams}

The source of procuring animals is the crucial factor as it significantly influences breeding performance and subsequent management practices. The adoption of better practices reflects the economics of the enterprise.

The rams used in the flock for breeding purposes are mainly home grown (55.83\%).
The farmers develop a special preference for the best home grown rams. But it would lead to inbreeding and lowered performance. About one-fifth of the respondents (18.33\%) are hiring the rams during the breeding season, which avoids maintenance of breeding rams.

The same $17.50 \%$ of the sheep farmers were purchasing the rams during the breeding season. No doubt, it is a good practice, as it introduces new germplasm into the flock, provided they are purchased from the credible source. Only four respondents resorted to the practice of ram exchange, which can be ignored, as the magnitude of the response is very less.

\section{Ewes}

The majority of the sheep farmers are building their flocks from the ewe lambs born in their flock. Only $12.50 \%$ of the respondents have purchased the ewes from outside sources. These few farmers are also either new entrants into this enterprise or would like to strengthen their flock.

\section{Adoption of sheep husbandry practices}

\section{Housing}

Proper housing is necessary to protect the sheep from extreme weather and predators. The $82.50 \%$ farmers possess kutcha house (a temporary house with mud walls and roof made up of tree leaves and other waste materials). These animal houses are having less ventilation and mud flooring predisposing the stock for disease spread (Sharma 2001).

There is a need to educate the farmers to have a scientifically designed animal house with proper ventilation and drainage may be built with locally available material to prevent the disease outbreaks. 
Penning of sheep in agricultural fields after the harvest is a common practice in this state which is beneficial to both shepherds and land owner. However, care must be taken to protect the flocks from extreme climatic conditions.

\section{Breeding}

The rams are mixed with flock and all the flocks are going for the natural services. The sheep farmers keep the rams along with the flocks all through the year. Two breeding seasons exist in sheep. Main season extend between June - August during which period nearly $80 \%$ of the ewes come to estrus.

Off-season extends between January - March during which period remaining ewes come to estrus. They are exploiting the advantages of these breeding seasons to the maximum.

Only one fifth of the respondents are aware of the advantages of ram rotation. This aspects needs to be considered by the extension agencies and provide the required inputs through training programmes, on farm demonstrations etc so that farmers derive the benefit.

About $50 \%$ of the respondents are monitoring the ewe performance. It is a good sign that half of the respondents are monitoring the ewe performance, which indicates that they are aware of the advantages of it. The other respondents should be educated on these activities.

On the other hand, no single individual is following flushing of the breeding stock, which improves the conception rate considerably. The sheep farmers are to be thoroughly educated and the extension personnel should put the concerted efforts on this aspect.

\section{Management and feeding}

It was evident from the Table 3 that certain of the management practices are followed to a moderate extent such as culling of adult stock $(55.83 \%)$ and monitoring the ewes performance. But no respondents is adopting weaning, use of mineral supplement and providing pregnancy allowance.

Very few $(7.50 \%)$ are following the practice of lamb feeding. This is an alarming situation as the respondents are not aware of the important management practices. The Animal Husbandry Department, Extension agencies should strive hard to change the attitude of the farmers and make them to adopt the best management and nutrition practices.

These practices directly reflect on the profits of the enterprise. Better adoption of management practices makes the farming viable and sustainable.

\section{Health practices}

\section{Deticking and deworming practices}

Simple health care measures viz. deticking and deworming will dramatically improve the flock performance. The $39.17 \%$ and $46.67 \%$ farmers are following deticking and deworming. They too follow the above measures on occasions when government or non-government agencies take up mass deworming and deticking programmes.

There is a need to sensitize the farmers by informing them about the advantages of taking up such activities on regular basis. Even those few farmers who are taking up deworming activity, procure the required deworming agent not on the advice of veterinarians after conducting the faecal analysis, thus exploited by stockiest. 
Table.1 Characteristics of goat farmer

\begin{tabular}{|c|l|c|c|}
\hline S.No & Item & Frequency & Percentage \\
\hline $\mathbf{1}$ & Education & 39 & 32.50 \\
\hline & Illiterate & 51 & 42.50 \\
\hline & Literate & 27 & 22.50 \\
\hline & Upto Primary & 03 & 02.50 \\
\hline & Upto Secondary & & \\
\hline $\mathbf{2}$ & Family type & 79 & 65.83 \\
\hline & Joint & & 34.17 \\
\hline & Nuclear & 25 & \\
\hline $\mathbf{3}$ & Family size & 95 & 79.83 \\
\hline & Up to 5 members & & \\
\hline & 6 and above & 17 & 14.17 \\
\hline $\mathbf{4}$ & Other Livestock possession & 89 & 74.17 \\
\hline & Cattle possession & 59 & 49.17 \\
\hline & Buffalo possession & 37 & 30.83 \\
\hline & Goat & & \\
\hline & Backyard poultry & & \\
\hline
\end{tabular}

Table.2 Flock and Breed details

\begin{tabular}{|c|c|c|c|}
\hline S.No & Item & Frequency & Percentage \\
\hline \multirow[t]{3}{*}{1} & Breed & & \\
\hline & Malpuri & 33 & 27.50 \\
\hline & Non Descript/ Mixed flock & 87 & 72.50 \\
\hline \multirow[t]{6}{*}{2} & Flock Size & & \\
\hline & $<25$ & 22 & 18.33 \\
\hline & $26-50$ & 61 & 50.83 \\
\hline & $51-75$ & 13 & 10.83 \\
\hline & 76-100 & 13 & 10.83 \\
\hline & $>100$ & 11 & 09.17 \\
\hline \multirow[t]{10}{*}{3} & Sources of Rams & & \\
\hline & Home grown & 67 & 55.83 \\
\hline & Purchased & 21 & 17.50 \\
\hline & Exchange & 06 & 05.00 \\
\hline & Hire & 22 & 18.33 \\
\hline & No ram & 04 & 03.33 \\
\hline & Sources of Ewes & & \\
\hline & Home grown & 94 & 78.33 \\
\hline & Purchased & 15 & 12.50 \\
\hline & Rearing of wages/ shearing & 11 & 09.17 \\
\hline
\end{tabular}


Table.3 Sheep husbandry practices followed by farmers

\begin{tabular}{|c|c|c|c|}
\hline S. No & Item & Frequency & Percentage \\
\hline \multirow[t]{8}{*}{1} & \multicolumn{3}{|l|}{ Breeding } \\
\hline & Breeding seasons followed & & \\
\hline & June- August & 120 & 100 \\
\hline & January - March & 120 & 100 \\
\hline & Service- Natural & 120 & 100 \\
\hline & Awareness on Ram rotation & 29 & 24.67 \\
\hline & Monitoring of ewe performance & 62 & 51.67 \\
\hline & Non flushing of breeding stock & 120 & 100 \\
\hline \multirow[t]{7}{*}{2} & \multicolumn{3}{|l|}{ Management } \\
\hline & Culling of adult stock & 67 & 55.83 \\
\hline & Lambing & 109 & 90.83 \\
\hline & Non practice of Weaning & 120 & 100 \\
\hline & Lamb feeding & 09 & 7.50 \\
\hline & No Mineral feed supplement & 120 & 100 \\
\hline & No pregnancy allowance & 120 & 100 \\
\hline \multirow[t]{10}{*}{3} & \multicolumn{3}{|l|}{ Health practices } \\
\hline & Deticking & 47 & 39.17 \\
\hline & Regular Deworming & 56 & 46.67 \\
\hline & Immunization & 77 & 64.17 \\
\hline & \multicolumn{3}{|l|}{ Health care providers } \\
\hline & Regular consultation of VAS & 10 & 8.33 \\
\hline & Occasional consultation of VAS & 65 & 54.17 \\
\hline & Attending camps organized by AHD & 18 & 15.00 \\
\hline & Consultation of local trained personnel & 05 & 4.17 \\
\hline & No consultation & 23 & 19.17 \\
\hline \multirow[t]{4}{*}{4} & \multicolumn{3}{|l|}{ Housing } \\
\hline & Open air & 13 & 10.83 \\
\hline & Kutcha & 99 & 82.50 \\
\hline & Pucca & 08 & 06.67 \\
\hline
\end{tabular}

\section{Immunization}

The study area is endemic for certain diseases like Enterotoxaemia and Anthrax. Animal Husbandry department is taking up regular immunization programmes. That is the reason $64.17 \%$ of the farmers flocks are covered under vaccination programme.

\section{Health care providers}

Perusal of the Table 3 indicated that nearly $54.17 \%$ farmers approach veterinary doctor or para-veterinarians only occasionally. Lack of awareness and accessibility of veterinary service providers are the primary reasons. There is a dire need to strengthen the Animal Husbandry service sector through providing 
gross root level workers as most of the farmers are poor and cannot hire services of veterinarians. However, slow and concerted efforts must be made to stimulate affordable farmers to make use of paid veterinary clinics for efficient and timely service.

\section{References}

Raju D T, Gnana Prakash M, Viroji Rao S T and Srinivasa Reddy M 2006 Socioeconomic and livestock aspects of different production systems - Indian case study. Livestock Research for Rural Development. Volume 18, Article \#174. Retrieved March 30, 2008, from http://www.lrrd.org/lrrd18/12/raju 18174.htm

Sharma G R K 2001 Factors related with adoption level of farmers about improved sheep rearing practices. Indian Veterinary Journal 78(5):440441

\section{How to cite this article:}

Bacchu Singh, K. C. Meena, Deepa Indoria and Meena. G. S. 2020. Adoption of Improved Sheep Rearing Practices in the Eastern Part of Rajasthan, India. Int.J.Curr.Microbiol.App.Sci. 9(05): 271-277. doi: https://doi.org/10.20546/ijcmas.2020.905.030 